\title{
Use of relative risk test to evaluate the influence of the brand on beer acceptability
}

\section{Uso do teste do risco relativo para avaliar a influência da marca na aceitação de cerveja}

\author{
Suzana Maria Della Lucia ${ }^{1 *}$; Valéria Paula Rodrigues Minim²; \\ Carlos Henrique Osório Silva²; Luis Antonio Minim²; Paula de Aguiar Cipriano ${ }^{3}$
}

\begin{abstract}
The acceptance of the product is very complex and it involves not only its sensory attributes but also non-sensory characteristics, often presented in the packaging or related to concepts regarding the consumer. The relative risk test was applied in order to investigate the effect of the brand, a nonsensory characteristic, on consumers' acceptance of beer. Eight commercial brands of Pilsen beer were evaluated by 101 consumers in two sessions of acceptance tests: the blind test and the test with brand information. As a general view, it could be concluded that three brands of beer showed a positive impact over the sensory acceptance of the product and four brands negatively impacted on consumers' evaluation. One of the brands did not show any influence over the consumers' response. The relative risk method was practical and useful as it was easily calculated and reproduced, and its application permitted easy interpretation of the results.
\end{abstract}

Key words: Sensory analysis, non-sensory characteristics, packaging, relative risk

\section{Resumo}

A aceitação de um produto é muito complexa e envolve não apenas seus atributos sensoriais, mas também inúmeros outros fatores, os fatores ou características não sensoriais, muitas vezes veiculados na própria embalagem, e outras tantas relacionados aos conceitos do próprio consumidor. $\mathrm{O}$ teste de estimativa do risco relativo foi aplicado a fim de se estudar o efeito da marca, característica não sensorial, sobre a aceitação de cerveja pelo consumidor. Oito marcas comerciais de cerveja tipo Pilsen foram avaliadas por 101 consumidores em duas sessões de testes de aceitação: teste cego e teste de aceitação da amostra na presença da embalagem (teste com informação). Como uma visão geral proporcionada pela estimativa do risco relativo para as oito amostras estudadas, pode-se concluir que, para as cervejas, três marcas exerceram impacto positivo na aceitação sensorial do produto e quatro marcas influenciaram negativamente na avaliação do consumidor. Uma das marcas não exerceu influência sobre a avaliação dos consumidores. O teste do risco relativo demonstrou ser prático e útil, sendo facilmente calculado e reproduzido, e sua aplicação permitiu fácil interpretação dos resultados.

Palavras-chave: Análise sensorial, características não sensoriais, embalagem, risco relativo

\footnotetext{
${ }^{1}$ Prof $^{\mathrm{a}}$ da Universidade Federal do Espírito Santo, Centro de Ciências Agrárias, UFES, Alegre, ES, Brasil. E-mail: smdlucia@ yahoo.com.br

${ }^{2}$ Profs. da Universidade Federal de Viçosa, UFV, Viçosa, MG, Brasil. E-mail: vprm@ufv.br; chos.ufv@gmail.com; lminim@ufv.br

${ }^{3}$ Discente de Doutorado em Ciência de Alimentos,Texas A\&M University, College Station, Texas, EUA. E-mail: pcipriano@ hotmail.com

* Author for correspondence 


\section{Introduction}

The satisfaction of the consumer towards any type of food comes from their positive perception regarding the quality of that product. Therefore, it must be kept in mind that the consumer is the one who should impose the quality parameters of a product. In studies involving food sensory analysis, as those related to acceptance and preference tests, a consumer is the fundamental object when measuring the sensory quality of a food. It is not worth to have a food presenting the desired physical, chemical and microbiological characteristics or even being better than its competitors, when this food is not appreciated by the consumers when it comes to its appearance, aroma, flavor and texture.

However, the acceptance of the product is much more complex and involves concepts of several fields. It is known today that not only the sensory attributes are responsible for the acceptance of a product. Consumers make use of several other factors in order to make their judgments and decide when choosing, consuming, appreciating and reusing the product. These other factors are called the nonsensory factors or non-sensory characteristics, often presented in the packaging or in the label or related to concepts regarding the consumer. Consumers are, thus, influenced by extrinsic information related to the product as well, such as the brand, packaging or label. Thus the product is selected by means of informations provided on it (CAPORALE et al., 2006) and by the interaction between those information and the own values and attitudes of the consumers. The assumption of this important relationship between non-sensory characteristics and consumption behavior has been studied by several researchers. Origin and technology involved in food production, convenience, brand name, price, ethnic and cultural values, age, monthly income and gender are some of the factors which exert great influence on the choice, purchase and acceptance of food (CAPORALE; MONTELEONE, 2004; DI MONACO et al., 2004; ARRUDA et al., 2006; IACCARINO et al., 2006; LOCKSHIN et al., 2006;
HEARTY et al., 2007; JAEGER; CARDELLO, 2007; JUST; HEIMAN; ZILBERMAN, 2007; OAKES; SULLIVAN; SLOTTERBACK, 2007; OLSEN et al., 2007; ARES; GIMÉNEZ; DELIZA, 2010; VARELA et al., 2010; CHUNG et al., 2012).

Of all the above mentioned attributes, the brand is certainly a non-sensory characteristic that deserves a special attention. The brand itself summarizes a series of thoughts, perceptions and attitudes concerning the consumers which are related to the specific product. When consumers are aware of the brand, they can perform a quick and fairly brief analysis over the quality and relevance of that product according to their necessities and desires (DELLA LUCIA et al., 2010).

In the last decades, several methods have been utilized aiming the understanding of consumers' behavior towards some types of food or products, in studies regarding both the field of marketing and the field of sensory analysis. The results of the sensory tests with consumers are traditionally analyzed either by means of the frequency distribution of hedonic scores or by the analysis of variance, or by means of an internal preference mapping (MacFIE; THOMSON, 1988; GREENHOFF; MacFIE, 1994; McEWAN, 1996; REIS; MINIM, 2010). However, other methods can be used with the same purpose. Actually, researches about the behavior of consumption quite frequently involve the study of the consumers' choice among discrete or categorical alternatives. In sensory analysis researches, for instance, acceptance tests generally use categorical scales such as the group of nine hedonic categories which vary from "extremely disliked" to "extremely liked". Still in cases of sensory acceptance studies, the responses of the consumers can be analyzed in terms of bad or good scores. That indicates that the researcher has in hands a group of binary responses ( good/bad), which is the tool in the study of the relative risk estimate (AGRESTI, 1990).

The technique of the relative risk estimate is applied in various areas of knowledge. However, 
its application in the field of sensory analysis is recent. Once this tool has been recently described for evaluation of data from acceptance tests with hedonic scales (DELLA LUCIA et al., 2010), yet there are few studies that have applied this technique, and it is described in the literature its use in sensory tests of the influence of brand name on the acceptance of processed cheese (MINIM et al., 2012).

Therefore, this work aimed at using the relative risk test in order to verify the influence of the brand on beer acceptance. Specifically, this research tried to explicit the probability of obtaining bad hedonic scores for the beer samples, in the blind tests as well as in the tests with brand information, which then allowed a conclusion about the impact of the brand on consumers' behavior. Furthermore, we tried to verify the practicality and usefulness of the relative risk test to evaluate the influence of a non-sensory characteristic on consumers' acceptance.

\section{Material and Methods}

This project was registered under number 50703155996 - Research Committee - Federal University of Viçosa, and it was conducted according to technical standards for ethics.

\section{Brands of beer}

Eight Brazilian beer brands of the Pilsen type were used in the experiment. The brands were coded in this text with letters ranging from $\mathrm{A}$ to $\mathrm{H}$. The choice of the brands was conducted based on three criteria:

$1^{\circ}$ ) according to a research conducted by DataFolha Institute, a Brazilian institute of research and statistics, regarding brands with the highest and lowest prevalence of responses when consumers were required to mention brands of beer. Based on this research, brands A, C and D jointly accounted for most of the responses given by the interviewees and brands B, E, F and G were less mentioned by the participants.

$2^{\circ}$ ) for the option of including a brand recently launched in the national market, brand $\mathrm{H}$, which has been an interesting object of research to find out the influence of an unfamiliar brand over the consumers' acceptance of beers; and

$\left.3^{\circ}\right)$ the availability of brands in the market of Viçosa, Minas Gerais State, Brazil, since the experiment was conducted with consumers residing in this city.

\section{Acceptance tests}

First of all, 101 volunteers, ranging from 18 to 58 years old, were recruited in order to compose the sensory panel of acceptance tests. There were among them students and employees of the Federal University of Viçosa (UFV) as well as residents of the city of Viçosa. The pre-requisite for the volunteers to participate in the research was that they had the habit of consuming beer and were available to attend to all the sessions of the tests. Therefore, the sample selected did not represent the population of Brazilian beer consumers, but it worked as an example to demonstrate the relative risk test, presented here as an analysis regarding the study of the influence of extrinsic product factors on the acceptance of the consumers.

The acceptance tests were carried out in the Sensory Analysis Laboratory of the UFV, in two sessions, with intervals of at least eight hours between the sessions, in order to avoid sensory fatigue in the judges.

In the first session (blind test), the consumers tasted the samples which were served in acrylic cups (with capacity of $40 \mathrm{~mL}$ ), without having any previous information regarding the brand of beer being evaluated. In this session, each of the eight brands was coded with a random three-digit number. 
The acceptance of the beer samples, served along with the respective packaging, was conducted in the second session (test with information), in which it was requested that the consumer judged the beverage, aware of the fact that the product being tasted was taken from the product contained in the packaging.

In each session, the evaluation were carried out in individual booths and the samples were served in a random and monadic way, at refrigerated temperature $\left(6^{\circ} \mathrm{C}\right.$ to $\left.8^{\circ} \mathrm{C}\right)$ (CAPORALE; MONTELEONE, 2004), under white light. In all sessions, the judges received a response form for each sample, in which it was requested that they indicated, in a hedonic scale of nine points, their acceptance towards the product, attributing scores which varied from "extremely liked" (corresponding to score 9) to "extremely disliked" (corresponding to score 1), according to Della Lucia et al. (2006).

By conducting these two sensory sessions, we can evaluate the influence of the brand on beer sensory acceptance. We chose to refer to the influence of the brand on consumer response and not to generalize to the effect of packaging itself, even though the packaging was shown to the consumers. This choice was made because the brand is characterized by a sum of factors or attributes found in the package, like symbols, drawings or expressions (KOTLER; ARMSTRONG, 2003), and not only by its name or word itself. We can infer then that the set of factors that characterize the brand actually causes impact on consumer decisions. For a product such as beer, the image generated by brand and its attributes seems to have great impact on consumer behavior, especially since there is little additional information shown in beer packaging.

\section{Relative risk estimate}

The objective of this analysis was to compare the probability of obtaining a score which was lower or equal to 5 from the blind test and from the test with information. Therefore, it was possible to have access to the effect of the brand on the consumers' assessment. In this analysis, it was considered that an hedonic score lower or equal to 5 was a bad score (the category "indifferent" in the hedonic scale was considered a bad score since it denotes a judgment which is little favorably to the acceptance of the product), whereas an hedonic score higher or equal to 6 was considered to be good or positive in the judgment of the sample.

To conduct the analysis, a table of frequencies was used with double entries, with the type of test (blind test and test with information) represented in the lines and the type of response (good or bad) represented in the columns (Table 1).

Table 1. Table of frequencies of good and bad scores obtained from the blind tests and from the information tests, organized for each brand of beer.

\begin{tabular}{lccc}
\hline & \multicolumn{2}{c}{ Response } & Total \\
\cline { 2 - 4 } Test & Good Score $^{\mathrm{a}}$ & Bad Score $^{\mathrm{b}}$ & 101 \\
\hline Blind & $\mathrm{n}_{11}$ & $\mathrm{n}_{12}$ & 101 \\
With information & $\mathrm{n}_{21}$ & $\mathrm{n}_{22}$ & \\
\hline Total & $\mathrm{n}_{1}$ & $\mathrm{n}_{2}$ & \\
\hline
\end{tabular}

${ }^{\mathrm{a}}$ Good score: a hedonic score higher or equal to 6.

${ }^{\mathrm{b}}$ Bad score: a hedonic score lower or equal to 5 .

Source: Elaboration of the authors. 
The relative risk is defined as being a comparison between two probabilities, i.e., comparing the risk of obtaining a determined response from two distinct conditions. In this study, it was defined that the relative risk would be used to compare the risk of obtaining bad hedonic scores from the blind test with the same risk from the test with information. Based on Table 1, it can be defined that:

$$
R_{1}=\frac{n_{12}}{101}
$$

is the risk in the blind test (estimate of the probability of having a bad answer in the blind test); it is the quotient between the total bad scores in the blind test by the total responses in the blind test;

$$
R_{2}=\frac{n_{22}}{101}
$$

is the risk in the test with information (estimate of the probability of having a bad answer in the test with information); it is the quotient between the total bad scores in the test with information by the total responses in the test with information.

The relative risk (RR) is given by (AGRESTI, 1990):

$$
R R=\frac{R_{1}}{R_{2}}=\frac{n_{12}}{n_{22}}
$$

The null hypothesis $\mathrm{H}_{0}$ for this analysis is that $\mathrm{RR}$ is equal to 1 , that means, the risks of having a bad score in the blind test and in the test with information are the same, thus the brand exerts no effect on the consumers' response and the probability of obtaining one answer does not depend on the probability of obtaining another one. For the alternative hypothesis $\left(\mathrm{H}_{\mathrm{a}}\right)$, if $\mathrm{RR}$ is greater than 1 , it can be concluded that the risk of having a bad score is higher in the blind test, which suggests a positive impact of the brand on the evaluation of the samples. On the other hand, for values of RR lower than the unit, it can be concluded that the risk of receiving bad scores in the blind test is smaller; hence the brand exerts a negative impact on consumers' evaluation.

The confidence interval (CI) at $95 \%$ of probability for the RR is obtained from (KLEINBAUM; KUPPER; MORGENSTERN, 1982):

$$
C I(R R)_{(1-\alpha) 100 \%}=\left\lfloor R R \times e^{(-z \sqrt{V})} ; \quad R R \times e^{(z \sqrt{V})}\right\rfloor,
$$

where:

$$
V=\operatorname{var}(\ln R R)=\frac{\left(1-P_{1}\right)}{n_{12}}+\frac{\left(1-P_{2}\right)}{n_{22}}
$$

var $=$ variance estimator; $P_{i}=R_{i}, i=1,2$; and $\mathrm{z}=$ value of the standardized normal distribution $[\mathrm{z} \sim \mathrm{N}(0,1)]$, corresponding to the desired level of confidence $(1-\alpha)$. The hypothesis $\mathrm{H}_{0}$ is rejected if the $\mathrm{CI}$ does not include the value 1 .

When analyzing the relative risk estimate, one can infer on the fact that the brand have or not influence on the sensory acceptance of the samples, and whether this is a positive or negative influence.

The statistical analysis were conducted by means of the Statistical Analysis System program (SAS SAS Institute Inc., North Carolina, USA, version 9.0), licensed for usage at UFV.

\section{Results and Discussion}

A summary of the results of the analysis of the relative risk of obtaining bad scores for the different brands of beer is presented on Table 2 . 
Table 2. Relative risk estimates for the obtainment of bad scores for the eight brands of beer from the blind test and from the test with information and the influence of the brand on consumers' evaluation.

\begin{tabular}{cccc}
\hline Brand & Relative Risk Estimate & Confidence Interval (95\%) & Conclusion ( $\left.^{\text {a }}\right)$ \\
\hline A & 0.5263 & $0.3303 \leq \mathrm{IC} \leq 0.8387$ & Negative Influence \\
B & 2.2105 & $1.3865 \leq \mathrm{IC} \leq 3.5243$ & Positive Influence \\
C & 2.8182 & $1.5007 \leq \mathrm{IC} \leq 5.2922$ & Positive Influence \\
D & 2.1333 & $1.2335 \leq \mathrm{IC} \leq 3.6894$ & Positive Influence \\
E & $0.9394^{\text {ns }}$ & $0.6264 \leq \mathrm{IC} \leq 1.4088$ & No Influence \\
F & 0.5600 & $0.3863 \leq \mathrm{IC} \leq 0.8119$ & Negative Influence \\
G & 0.5098 & $0.3474 \leq \mathrm{IC} \leq 0.7480$ & Negative Influence \\
H & 0.5556 & $0.3710 \leq \mathrm{IC} \leq 0.8318$ & Negative Influence \\
\hline
\end{tabular}

a Negative influence: the brand exerts a negative impact on beer acceptance; positive influence: the brand exerts a positive impact on beer acceptance; no influence: the brand does not exert impact on beer acceptance.

ns: not significant.

Source: Elaboration of the authors.

It can be verified that the calculated CI's for $\mathrm{B}, \mathrm{C}$ and $\mathrm{D}$ brands did not include the value 1 ; besides, the relative risk estimate for those brands were greater than one. This indicates that the brand exerted a positive influence to the consumers of this study on the sensory acceptance concerning the test with information (see Equation 3). As observed for brands $\mathrm{C}$ and $\mathrm{D}$, two of the most mentioned beer brands by the interviewees of the DataFolha survey, when the brand is well known, it tends to change the responses of the consumers regarding some samples (DI MONACO et al., 2004; CARNEIRO, 2007). This corroborates the fact that the familiarity or the consumers' knowledge about such product had some influence on its evaluation, when such information about the product was provided during the sensory analysis. Hence, the known sample tend to be accepted (even if not completely accepted when being tasted) when its non-sensory characteristics are known, i.e., when such characteristics are provided (ARRUDA et al., 2006).

Guinard, Uotani and Schlich (2001) applied the techniques internal and external preference mapping to compare consumers' hedonic responses in blind and information tests of commercial lager beers. It was provided to the consumers information about brand and price in the informed sensory test. The authors found out that hedonic ratings changed significantly from the blind to the informed evaluating condition, particularly for consumers in their twenties, thereby proving the significant role of non-sensory attributes in the formulation of a hedonic judgement. In a study conducted in France, it was observed that the sensory acceptance of Champagne, a beverage widely consumed in that country, was always associated to the brand reputation and the selling price of the bottle, once the most familiar brands and with the higher price were also the most accepted beverages (LANGE et al., 2002).

Brand B, although being a brand which was less mentioned by the participants of the survey, had higher acceptance in the test with information, in comparison to the one obtained from the blind test.

When it comes to beers A, F, G and H, it could be concluded that the information about the brand modified the acceptance of the samples in a negative way since those samples received worse judgments in the test with information when compared to the blind test. Brands $F$ and $G$ were two of the less mentioned brands by the participants of the survey used as a criterion of choice of the brands used in the present work. Although brand A were one of the beer brands most mentioned in the survey, it caused a negative impact on consumers' acceptance in this study. The brand $\mathrm{H}$, recently launched in 
the Brazilian market, was one of the brands which caused a negative impact on consumers' acceptance, probably because it is an unfamiliar brand to the participants of this study.

For beer E, the analysis led to the conclusion that the brand did not cause any influence on the sensory judgment of the consumers (relative risk estimate was not significant).

As it could be verified, the brand A presented a negative impact on the acceptance of beer sample, although it was one of the most mentioned beer brand in DataFolha Institute research. A contrary situation was observed for brand B. However, it is noteworthy that the use of that research served only as a guidance for choosing the brands to be used in the acceptance testing of this work. Besides, small differences between that research and this study could occur, since the sample of participants used in this study did not represent the population of Brazilian beer consumers, as previously mentioned.

Varela et al. (2010) studied the influence of brand information on consumers' expectations and liking of orange-flavoured powdered drinks. They concluded that consumers' perception of the brands had a larger impact on informed liking scores than sensory characteristics, suggesting that blind conditions might not appropriately predict consumers' affective reaction to this food. This suggestion seems to be applicable to beer, at least to most commercial beers used in the present study. This indicates that the manufacturers of beer must pay careful attention and must work on the marketing strategy of his product, since, if the brand operates as a "silent salesman" in an improper way (from the consumers' point of view), it tends to repel its market. Besides, one can infer that brand, a non-sensory characteristic, should be taken into account during the process of new product development, such as beer development, since they could significantly affect consumers' response.

\section{Conclusions}

As a general view, it can be concluded that three brands of beer caused a positive impact on the sensory acceptance of the product, and four brands negatively influenced on the consumers' evaluation. Besides that, one of the brands did not cause any influence on consumers' response.

The relative risk test demonstrated to be a simple way to interpret results obtained from this study, concerning the influence of the brand on beer acceptance, consisting of a practical and useful tool. Besides that, it is a test that requires simple calculations and which can be easily reproduced by hand, allowing easy understanding to its users regarding its objectives and utilization, as well as providing an easy interpretation of the results.

\section{Acknowledgments}

The authors would like to thank the Foundation of Research Support of Minas Gerais State (FAPEMIG) and the National Council for Scientific and Technological Development (CNPq) for the financial support.

\section{References}

AGRESTI, A. Describing two-way contingency tables. In: . Categorical data analysis. New York: John Wiley \& Sons, 1990. cap. 2, p. 8-35.

ARES, G.; GIMÉNEZ, A.; DELIZA, R. Influence of three non-sensory factors on consumer choice of functional yogurts over regular ones. Food Quality and Preference, Oxford, v. 21, n. 4, p. 361-367, 2010.

ARRUDA, A. C.; DELla LUCIA, S. M.; DIAS, B. R. P.; MINIM, V. P. R. Cafés convencional, orgânico e descafeinado: impacto da informação na sua aceitação. Revista Brasileira de Armazenamento, Especial Café, Viçosa, n. 9, p. 94-99, 2006.

CAPORALE, G.; MONTELEONE, E. Influence about manufacturing process on beer acceptability. Food Quality and Preference, Oxford, v. 15, n. 3, p. 271278, 2004. 
CAPORALE, G.; POLICASTRO, S.; CARLUCCI, A.; MONTELEONE, E. Consumer expectations for sensory properties in virgin olive oils. Food Quality and Preference, Oxford, v. 17, n. 1-2, p. 116-125, 2006.

CARNEIRO, J. D. S. Estudo dos fatores da embalagem $e$ do rótulo de cachaça no comportamento dos consumidores. Viçosa, 2007. Tese (Doutorado em Ciência e Tecnologia de Alimentos) - Departamento de Tecnologia de Alimentos. Universidade Federal de Viçosa, Viçosa, MG. Disponível em: <http://www.tede. ufv.br/tedesimplificado/tde_arquivos/38/TDE-200706-28T115052Z-605/Publico/texto\%20completo.pdf $>$. Acesso em: 18 maio 2012.

CHUNG, L.; CHUNG, S. J.; KIM, J. Y.; KIM, K. O.; O'MAHONY, M.; VICKERS, Z.; CHA, S. M.; ISHII, R.; BAURES, K.; KIM, H. R. Comparing the liking for Korean style salad dressings and beverages between US and Korean consumers: effects of sensory and nonsensory factors. Food Quality and Preference, Oxford, v. 26, n. 1, p. 105-118, 2012.

DELLA LUCIA, S. M.; ARRUDA, A. C.; DIAS, B. R. P.; MINIM, V. P. R. Expectativa gerada pela embalagem na aceitação de iogurte sabor morango. Revista do Instituto de Laticínios Cândido Tostes, Juiz de Fora, v. 351, n. 61, p. 148-151, 2006.

DELLA LUCIA, S. M.; MINIM, V. P. R.; SILVA, C. H. O.; MININ, L. A. Características não sensoriais e o comportamento do consumidor: conceitos e métodos estatísticos de avaliação. In: MINIM, V. P. R. (Ed.). Análise sensorial: estudos com consumidores. 2. ed. Viçosa: Editora UFV, 2010. cap. 6, p. 125-167.

DI MONACO, R.; CAVELLA, S.; DI MARZO, S.; MASI, P. The effect of expectations generated by brand name on the acceptability of dried semolina pasta. Food Quality and Preference, Oxford, v. 15, n. 5, p. 429-437, 2004.

GREENHOFF, K.; MacFIE, H. J. H. Preference Mapping in Practice. In: MACFIE, H. J. H.; THOMSON, D. M. H. Measurement of food preferences. London: Blackie Academic and Professional, 1994. p. 137-165.

GUINARD, J. X.; UOTANI, B.; SCHLICH, P. Internal and external mapping of preferences for commercial lager beers: comparison of hedonic ratings by consumers blind versus with knowledge of brand and price. Food Quality and Preference, Oxford, v. 12, n. 4, p. 243-255, 2001.

HEARTY, Á. P.; McCARTHY, S. N.; KEARNEY, J. M.; GIBNEY, M. J. Relationship between attitudes towards healthy eating and dietary behaviour, lifestyle and demographic factors in a representative sample of Irish adults. Appetite, Netherlands, v. 48, n. 1, p. 1-11, 2007.

IACCARINO, T.; DI MONACO, R.; MINCIONE, A.; CAVELLA, S.; MASI, P. Influence of information on origin and technology on the consumer response: the case of soppressata salami. Food Quality and Preference, Oxford, v. 17, n. 1-2, p. 76-84, 2006.

JAEGER, S. R.; CARDELLO, A. V. A construct analysis of meal convenience applied to military foods. Appetite, Netherlands, v. 49, n. 1, p. 231-239, 2007.

JUST, D. R.; HEIMAN, A.; ZILBERMAN, D. The interaction of religion and family members' influence on food decisions. Food Quality and Preference, Oxford, v. 18, n. 5, p. 786-794, 2007

KLEINBAUM,D.G.;KUPPER,L.L.;MORGENSTERN, H. Epidemiologic research: principles and quantitative methods. Research Methods Series, New York: Van Nostrand Reinhold, 1982. 560 p.

KOTLER, P.; ARMSTRONG, G. Estratégia de produtos e serviços. In: KOTLER, P.; ARMSTRONG, G. Princípios de marketing. 9. ed. São Paulo: Editora Pearson Prentice Hall, 2003. cap. 8, p. 203-236.

LANGE, C.; MARTIN, C.; CHABANET, C.; COMBRIS, P.; ISSANCHOU, S. Impact of the information provided to consumers on their willingness to pay for champagne: comparison with hedonic scores. Food Quality and Preference, Oxford, v. 13, n. 7-8, p. 597-608, 2002.

LOCKSHIN, L.; JARVIS, W.; d'HAUTEVILLE, F.; PERROUTY, J. P. Using simulations from discrete choice experiments to measure consumer sensitivity to brand, region, price and awards in wine choice. Food Quality and Preference, Oxford, v. 17, n. 3-4, p. 166-178, 2006.

MacFIE, H. J. H.; THOMSON, D. M. H. Preference Mapping and Multidimensional Scaling. In: PIGGOT, J. R. Sensory analysis of foods. 2. ed. New York: Elsevier, 1988. p. 38-409.

McEWAN, J. A. Preference mapping for product optimization. In: NAES, T.; RISVIK, E. Multivariate analysis of data in sensory science. Amsterdam: Elsevier, 1996. p. 71-101.

MINIM, V. P. R.; MILAGRES, M. P.; SILVA, R. C. S. N.; VASCONCELOS, C. M.; MARTINS, E. M. F.; SAMPAIO, S. C. S. Análise de risco na avaliação da influência da marca na aceitabilidade não sensorial de requeijão cremoso. Revista do Instituto de Laticínios Cândido Tostes, Juiz de Fora, v. 387, n. 67, p. 79-85, 2012. 
OAKES, M. E.; SULLIVAN, K.; SLOTTERBACK, C. S. A comparison of categorical beliefs about foods in children and young adults. Food Quality and Preference, Oxford, v. 18, n. 5, p. 713-719, 2007.

OLSEN, S. O.; SCHOLDERER, J.; BRUNSØ, K.; VERBEKE, W. Exploring the relationship between convenience and fish consumption: a cross-cultural study. Appetite, Netherlands, v. 49, n. 1, p. 84-91, 2007.
REIS, R. C.; MINIM, V. P. R. Teste de aceitação. In: MINIM, V. P. R. (Ed.). Análise sensorial: estudos com consumidores. Viçosa: Editora UFV, 2010. cap. 3, p. 6682.

VARELA, P.; ARES, G.; GIMÉNEZ, A.; GÁMBARO, A. Influence of brand information on consumers' expectations and liking of powdered drinks in central location tests. Food Quality and Preference, Oxford, v. 21, n. 7, p. 873-880, 2010. 
